\title{
CONTINUES PROCESS IMPROVEMENT DENGAN ROBUST DESIGN DALAM CLEANER PRODUCTION : PROSES PRODUKSI CaO
}

\author{
Deny Andesta \\ Jurusan Teknik Industri \\ Universitas Muhammadiyah Gresik \\ Email : deny_andesta@yahoo.com
}

\begin{abstract}
ABSTRAK
PT. Giri Mulya Jatim adalah perusahaan yang memproduksi kapur aktif $(\mathrm{CaO})$ untuk industri. Kualitas $\mathrm{CaO}$ yang dihasilkan dari proses pembakaran batu kapur $\left(\mathrm{CaCO}_{3}\right)$ masih rendah dengan kadar persentase $\mathrm{CaO}$ dibawah 45,6 $\%$. Disamping itu masih adanya cacat berupa batu curing sebesar 5\%. Penelitian ini mengaplikasikan pendekatan perbaikan proses berkesinambungan. Faktor yang dominan yang teridentifikasi sebagai penyebab ketidaksesuaian persentase kadar $\mathrm{CaO}$ adalah jenis bahan bakar, ukuran batu kapur dan jenis batu kapur. Dari hasil eksperiment Taguchi, faktor yang berpengaruh secara signifikan terhadap respon persentase kadar $\mathrm{CaO}$ adalah jenis bahan bakar kayu dan batu bara $\left(\mathrm{C}_{2}\right)$ dengan kontribusi 37.67\%, ukuran batu kapur dengan ukuran kecil $\left(\mathrm{B}_{1}\right)$ dengan kontribusi $26.49 \%$, interaksi antara jenis batu kapur dengan ukuran batu kapur $\left(\mathrm{A}_{2} \mathrm{~B}_{1}\right)$ dengan kontribusi 13.04\% serta interaksi antara jenis batu kapur dan jenis bahan bakar $\left(\mathrm{A}_{2} \mathrm{C}_{2}\right)$ dengan kontribusi 13.24\%. Cleaner production pada proses pembakaran batu kapur masih rendah karena efisiensi yang rendah dengan rugi-rugi berupa aliran panas yang terbuang percuma. Proses pembakaran batu kapur memberikan dampak pada tumbuhan jagung berupa spot bewarna putih kekuningan secara morfologis dan kerusakan pada stomata secara anatomis.
\end{abstract}

Kata kunci : Kualitas, Faktor, Taguchi, Cleaner Production.

\section{PENDAHULUAN}

Greens productivity merupakan suatu konsep penyelarasan socio-economic dan mekanisme dari perlindungan lingkungan, yang menjadi kunci dalam meningkatkan mutu kehidupan melalui pengembangan yang sustainable. Peningkatan mutu hidup sering dihubungkan dengan peningkatan untuk kebutuhan akan produk dan service. Peningkatan dalam produktivitas secara normal akan menghabiskan sumber daya dari alam dan menghasilkan limbah yang dapat merusak lingkungan. Greens productivity merupakan suatu strategi dalam pengembangan produktivitas dan pencapaian peformance lingkungan dari seluruh pengembangan socioeconomi yang sesuai dengan sistem manajemen dan teknologi untuk menghasilkan produk dan jasa.

Kehidupan sebuah produk dimulai dari sebuah kebutuhan yang berasal dari konsumen (voice of customer), diproduksi, dan siap dipergunakan melewati berbagai tahapantahapan seperti perancangan, produksi, testing, dipasarkan, dikembangkan, dan akhir dari kehidupan produk (recycle dan dibuang). Agar dapat diterima oleh konsumen, perusahaan berusaha melakukan pengembangan produk secara berkelanjutan (sustainable) (Gumus, 2005).

Para analis bisnis akan setuju bahwa dalam rangka untuk tetap bertahan pada pasar, perusahaan harus mengantisipasi pelanggan, dengan meningkatkan efficiency and effectiveness pada proses dalam rangka penurunan ongkos produksi serta sedang menuju standar mutu yang tinggi (Gilbert, 2003).

Pergeseran titik tolak pemikiran para eksekutif bisnis bahwa profitabilitas tidak cukup sebagai ukuran dalam kesuksesan dan banyak hal yang berhubungan dengan non financial yang mengarah pada sustainability sebagai dasar dari nilai shareholder untuk jangka panjang. Kegagalan untuk mengenali isu strategis ini (sustainability), ini akan mengancam keberlangsungannya bisnis suatu perusahaan. (Bakshi, 2003). Karena dalam isu sustainability seperti green manufaktur, life cycle assessment (LCA), ecolabelling, ecomaterials, cleaner production, zero emision dan sebagainya (Wang,2001), limbah merupakan 
sesuatu yang harus diminimumkan karena terkait dengan efektifitas dan efisiensi yang pada akhirnya dapat mengurangi biaya yang dikeluarkan untuk perbaikan lingkungan yang diiterintegrasikan dengan six sigma (Giardina, 2006), karena salah satu dari tiga perspektif sustainability mengarahkan pada produk atau service dengan meminimumkan waste pada resources (Bar. Et. All, 2004). Untuk itu perlu dilakukan aktivitas-aktivitas yang terkait dengan hal tersebut. Semua aktivitas yang terkait untuk mengurangi kerusakan pada lingkungan yang disebabkan oleh proses produksi dapat dikategorikan sebagai cleaner production (Bij, et all, 2004).

United Nations Enviroment Program (UNEP) mendefenisikan cleaner production sebagai suatu upaya penerapan yang berkelanjutan dari suatu strategi pengelolaan lingkungan yang terintegral dan preventif terhadap suatu proses dan produk untuk mengurangi terjadinya resiko terhadap manusia dan lingkungan. Untuk proses, cleaner production mencakup upaya konservasi bahan baku dan energi, menghindari pemakaian bahan yang mengandung B3 (bahan berbahaya dan beracun), mengurangi jumlah dan toksisitas semua limbah dan emisi yang dikeluarkan sebelum meninggalkan proses. Pada produk, cleaner production memfokuskan pada upaya pengurangan dampak dikeseluruhan daur hidup produk, mulai dari ekstrasi bahan baku sampai pembuangan akhir setelah produk tidak digunakan. Produk yang defect, merupakan suatu limbah karena tidak sesuai dengan kualitas yang diinginkan konsumen dan harus diminimalkan atau zero defect.

Pengawasan terhadap produk mutlak diimplementasikan sebagai jaminan pada konsumen bahwa produk yang dilemparkan ke pasaran memiliki mutu yang baik. Proses Quality Control dimulai pada saat bahan baku masuk gudang sampai proses yang terjadi pada tiap bagian di lantai produksi. Kualitas adalah derajat keseragaman dan kepercayaan, pada biaya yang rendah dan sesuai dengan pasar (Howard. G, 1995, Gitlow, 1987). Perusahaan harus secara kontinyu memenuhi spesifikasi produk yang memenuhi permintaan konsumen. Perbaikan proses untuk meningkatkan kualitas akan memberikan manfaat seperti : mengurangi rework, meningkatkan produktivitas, menekan biaya produksi per-unit, meningkatkan posisi yang kompetitif di pasar, dan profit yang lebih besar. Loss quality terjadi ketika proses menghasilkan produk dengan kualitas yang tidak dapat diramalkan keseragamannya, yaitu terdapat variasi yang tinggi dari unit-unit produk yang dibuat.

Usaha meningkatkan kualitas produk dapat dilakukan dengan menerapkan pendekatan Six Sigma yang mempunyai siklus DMAIC (Define, Measure, Analyze, Improve, dan Control). Six Sigma merupakan suatu methodologi yang sistematik, yang merupakan suatu utilizes tools, training dan alat ukur pada organiasi dalam merancang produk dan proses untuk menyesuaikan harapan konsumen serta dapat menghasilkan tingkatan kualitas six sigma (Mader, 2002). Six sigma dapat meningkatkan pengembangan produk baru dan sistem proses pengembangan, mengurangi resiko penggunaan tool seperti pandangan penggunaan tool kuantitative dan mengukur pengembangan berdasarkan proses untuk mengurangi atau menghilangkan kebutuhan subjektivitas (Hayes, 2003).

Perubahan batu kapur (Calcium Carbonate) menjadi quick lime $(\mathrm{CaO})$ dilakukan dengan proses kalsinasi atau pembakaran, sudah dikenal sejak dulu (Krumnacher, 2001) dan sudah dikenal luas oleh masyarakat kita sebagai bahan untuk pengapuran yang memberikan warna putih.

Kebutuhan kapur aktif $(\mathrm{CaO})$ pada industri sangat banyak (consumable) sehingga unit produksi kapur harus meningkatkan produksinya untuk memenuhui kebutuhan pasar serta meningkatkan kualitas produknya agar dapat bersaing dengan produk kapur yang lain.

Untuk mendapatkan calcium carbonate dilakukan dengan cara menambang dan diproses secara tradisional. Ini sudah banyak dilakukan di berbagai daerah penghasil batu kapur. Kendala dalam memproduksi kapur secara tradisional adalah kualitas $\mathrm{CaO}$, seperti kadar kapur aktif tidak bisa maksimal dan masih banyak terjadi defect berupa batuan curing, yang harus dipisahkan karena batuan curing merupakan batuan yang diambil dari tambang pada bagian permukaan dan juga terbentuk karena proses yang tidak sempurna sehingga tidak dapat diproses lebih lanjut. Disamping itu, kapasitas produksi yang rendah antara $25-30$ ton per 5 hari, dan juga dari sumber daya manusianya kurang mampu dalam memproses yang lebih efektif dan efisien, sehingga banyak terjadinya cacat (defect).

\section{Perumusan Masalah}

Dari permasalahan diatas, maka dapat dijelaskan bahwa permasalahan tersebut dapat dirumuskan 
yaitu Bagaimana melakukan perbaikan proses yang berkesinambungan dengan Robust Design pada kualitas produk $\mathrm{CaO}$ (quick Lime), serta heat loss dan dampak dari proses pembakaran batu kapur dalam Isu Cleaner Production?.

\section{Tujuan Penelitian}

Berdasarkan latar belakang masalah yang telah dijelaskan, maka tujuan yang akan dicapai dalam pelaksanaan penelitian ini, antara lain :

1. Mengidentifikasi faktor dominan penyebab ketidak sesuaian kandungan produk $\mathrm{CaO}$.

2. Menetukan setting parameter yang tepat sehingga dapat mengoptimalkan kualitas $\mathrm{CaO}$.

3. Menghitung heat loss dan dampak proses pembakaran batu kapur.

\section{Sustainability}

Kehidupan sebuah produk dimulai dari sebuah kebutuhan yang berasal dari konsumen (voice of customer), diproduksi, dan siap dipergunakan melewati berbagai tahapan-tahapan seperti perancangan, produksi, testing, dipasarkan, dikembangkan, dan akhir dari kehidupan produk (recycle dan dibuang). Agar dapat diterima oleh konsumen, perusahaan berusaha melakukan pengembangan produk secara berkelanjutan (sustainable) (Bulent, 2005).

Penggunaan berbagai sumber daya yang ada, tanpa terkontrol akan mengakibatkan kehabisan sumber daya dan ini memunculkan pergeseran perhatian para pelaku bisnis yang tidak hanya berorientasi pada produk, namun juga pada bisnis proses yang lebih mengarah kepada perhatian lingkungan, hal inilah yang mendorong berkembangnya konsep green industri.

Dengan demikian tidaklah mengherankan jika pada akhir-akhir ini tumbuh kesadaran baru dalam dunia usaha yang lebih berwawasan pada teknologi dan lingkungan yang terkait dengan isu sustainability.

Banyak peneliti yang mendefenisikan isu sustainability seperti Black(2005), mendefenisikan sustainability sebagai sesuatu yang dikembangkan secara berkelanjutan yang tidak dapat dipisahkan dari interaksi karakteristiknya dan lingkungan.

PBB yang mempunyai komisi tersendiri memberikan konsep dasar dari sustainable development (SD) yang didefenisikan lebih dari 15 tahun lalu oleh komisi U.N. dengan mengusulkan pengembangan kebutuhan manusia dan global ecosystems dengan mengarahkan pada kualitas hidup untuk generasi masa yang akan datang (WECD,1987).

Upaya pencegahan pencemaran secara sistematis dapat dilaksanakan melalui pelaksanaan program cleaner production. Cleaner production mencakup pendekatan secara konseptual dan operasional terhadap proses dan produk, dimana dampak dari seluruh daur hidup produk terhadap lingkungan dan manusia, dapat ditekan sekecil mungkin. Strategi cleaner production mencakup upaya pencegahan pencemaran melalui pilihan jenis proses yang akrab lingkungan, minimisasi limbah, analisis daur hidup dan teknologi bersih. Program cleaner production dapat diterapkan pada semua kegiatan yang menimbulkan dampak pencemaran, tanpa terbatas oleh skala dan tipe organisasi. Cleaner production merupakan sub system dari system sustainable development dan saling terkait dengan sub system lainnya seperti gambar1. (Carnegie, et all. 2000).

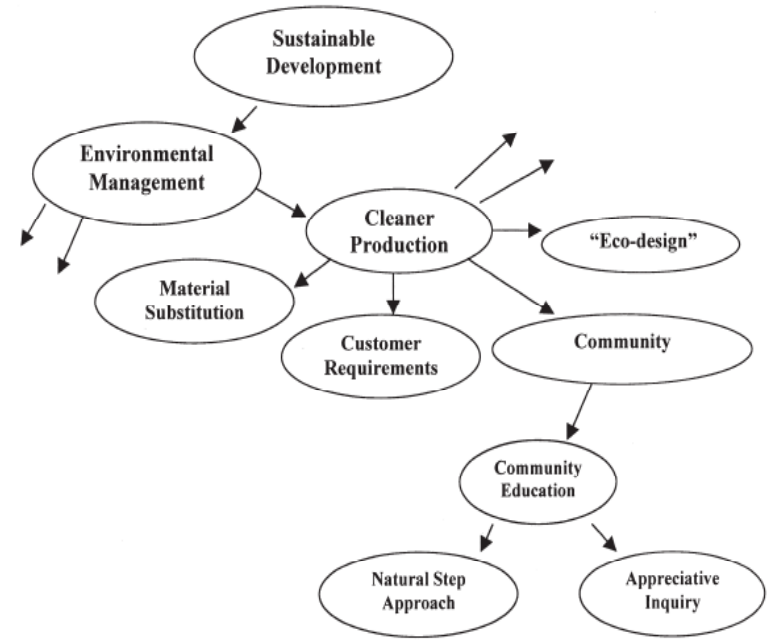

Gambar 1. System Cleaner production dan sub system yang terkait

Pada dasarnya, perusahaan akan mengeluarkan tiga jenis pembiayaan secara tidak langsung pada polusi, dan terkait dengan hasil yang non produk berupa limbah dan emisi (Gale, 2005) seperti : Pertama, perusahaan membayar biaya pembelian bahan baku (contoh, bahan bakar, air, dan bahankimia), proporsi yang dihasilkan dari akhir proses yang berupa limbah dan emisi. Kedua, perusahaan membayar biaya operasional penggunaan bahan baku melalui biaya-biaya tenaga kerja dan infrastruktur investasi, proporsi yang dihasilkan dari akhir proses yang berupa limbah dan emisi. Ketiga, perusahaan juga harus membayar biayabiaya penjualan untuk limbah material yang dibeli atau lisensi, yang mengijinkan limbah dengan suatu proporsi yang dihasilkan dari akhir proses 
yang berupa limbah dan emisi yang menyangkut biaya-biaya pembelian material.

Cleanerproductiontelahdibuktikan sebagaisuatu cara yang efektif dalam mencapai peningkatkan utilisasi dari material, mengurangi konsumsi energi dan menurunkan level emisi. Juga memotivasi tindakan pencegahan positif dan memperkenalkan pandangan holistic pada sumber daya, produksi, ekonomi dan lingkungan. (Kjaerheim, 2005).

\section{Six Sigma}

Sigma $(\sigma)$ adalah sebuah abjad Yunani yang menotasikan standar deviasi suatu proses. Standar deviasi mengukur variasi atau jumlah persebaran suatu rata-rata proses. Dengan kata lain, sigma merupakan unit pengukuran statistik yang mendeskripsikan distribusi tentang nilai rata-rata (mean) dari setiap proses atau prosedur. Suatu proses atau prosedur yang dapat mencapai lebih atau kurang kapabilitas Six Sigma dapat diharapkan memiliki tingkat cacat yang tidak lebih dari beberapa ppm (parts per million), meskipun mengizinkan untuk beberapa pergeseran dalam nilai rata-rata (mean). Dalam terminologi statistika, ini mencapai kegagalan nol (zero defects).

Tingkat kualitas sigma biasanya juga dipakai untuk menggambarkan variasi dari suatu proses. Semakin tinggi tingkat sigma maka semakin kecil toleransi yang diberikan padakecacatan dan semakin tinggi kemampuan proses. Sehingga variasi yang dihasilkan semakin rendah dan dapat mengurangi frekuensi munculnya defect, biaya-biaya proses, waktu siklus proses mengalami penurunan dan kepuasan customer meningkat. (Gaspersz,2002).

Pada dasarnya pelanggan akan puas jika mereka menerima nilai sebagaimana yang mereka harapkan. Apabila produk diproses pada tingkat kualitas Six Sigma, perusahaan boleh mengharapkan 3,4 kegagalan persejutakesempatanataumengharapkan bahwa 99,99966 persen dari apa yang diharapkan pelanggan akan ada dalam produk tersebut. Dengan demikian Six Sigma dapat dijadikan ukuran target kinerja sistem industri tentang bagaimana baiknya suatu proses transaksi produk antara pemasok (industri) dan pelanggan (pasar). Semakin tinggi target sigma yang dicapai, kinerja sistem industri akan semakin baik. Sehingga 6-sigma otomatis lebih baik daripada 4-sigma, 4-sigma lebih baik dari 3-sigma. Six Sigma juga dapat dipandang sebagai pengendalian proses industri berfokus pada pelanggan, melalui penekanan pada kemampuan proses (process capability).

\section{Batu Kapur (Limestone)}

Kapur banyak mengandung unsur Calsium Carbonate secara spesifik berwarna putih, abu - abu kuning tua, abu - abu kebiruan, jingga dan sedikit kehitaman, yang mempunyai berat jenis 2,6 - 2,8 dalam keadaan murni berbentuk kristal kalsit. Untuk mendapatkan calcium carbonate dilakukan dengan cara menambang dan diproses secara tradisional. Ini sudah banyak dilakukan di berbagai daerah penghasil batu kapur yang tersebar di berbagai daerah di Indonesia dan dipergunakan sebagai bahan baku untuk pembuatan semen.. Batu kapur dapat dibedakan atas cara proses yang dilakukan untuk mendapatkan hasil akhir seperti gambar 2. siklus lime (Krumnacher,2001):

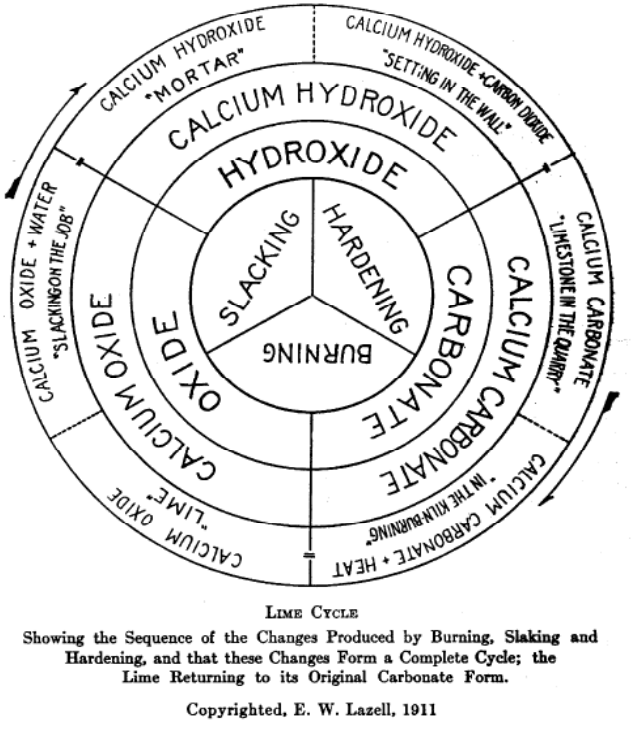

Gambar 2. Lime Cycle

\section{METODE}

Aliran kegiatan yang dilakukan dalam penelitian ini dibagi atas empat tahapan yang terbagi seperti di bawah ini :

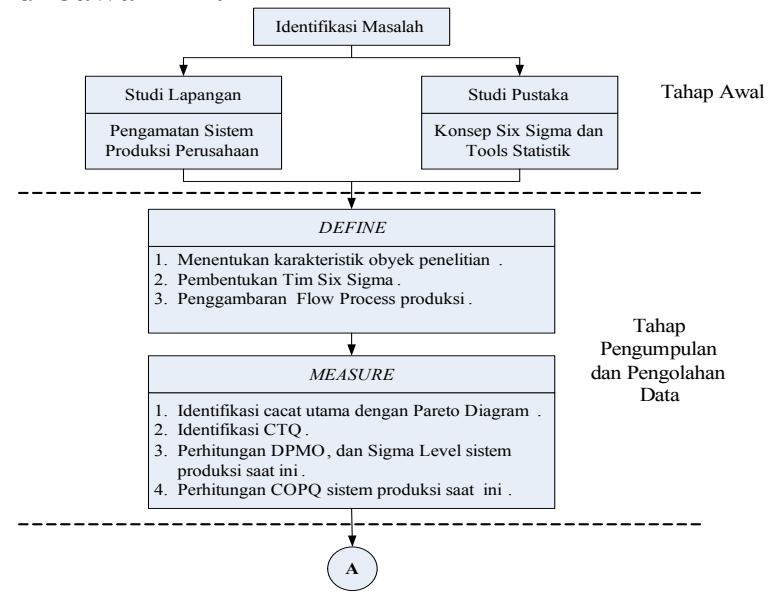




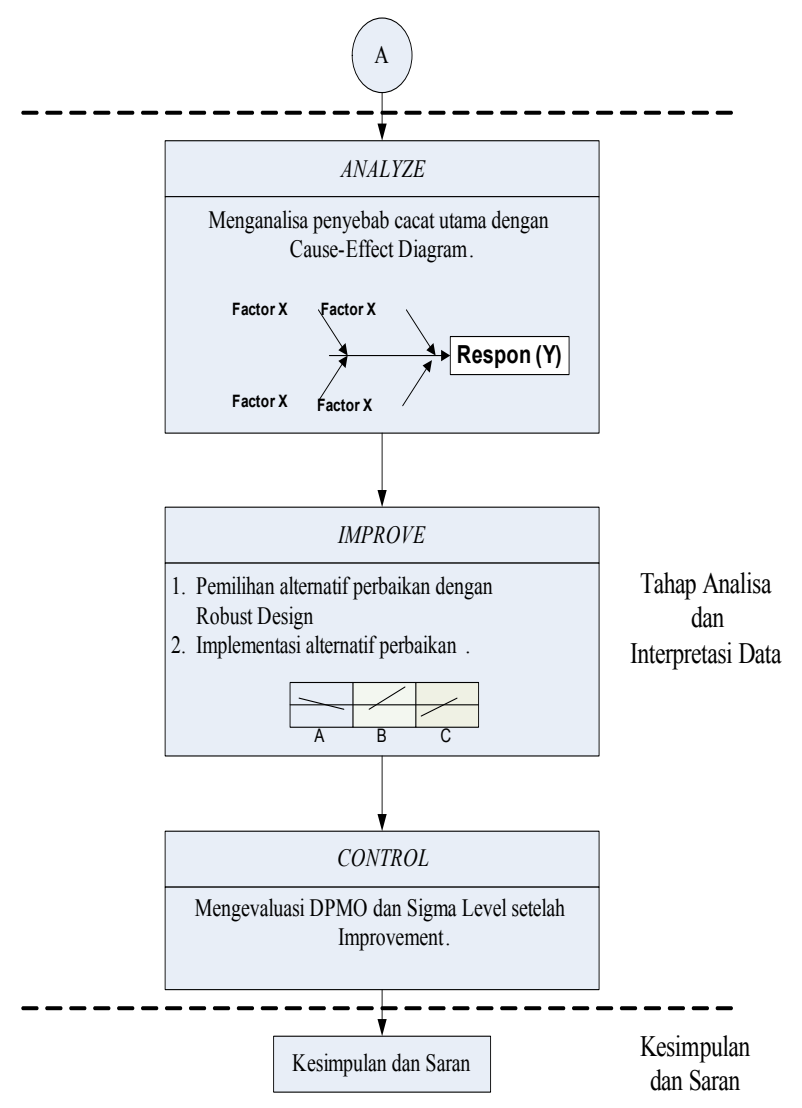

Gambar 3. Flowchart metodologi penelitian

\section{HASIL DAN PEMBAHASAN}

\section{Define}

Define merupakan langkah pertama dari siklus DMAIC dalam program peningkatan kualitas dengan Six Sigma.

\section{Identifikasi Kriteria Pemilihan Proyek}

Produk yang dihasilkan oleh PT. Giri Mulya Jatim adalah kapur aktif. Kapur aktif $(\mathrm{CaO})$ dihasilkan dari proses pembakaran batu kapur (Calcium Carbonat atau $\mathrm{CaCo}_{3}$ ). Defect yang teridentifikasi dari proses pembakaran tersebut adalah defect berupa batu curing dan berdasarkan hasil pengamatan dan wawancara diperoleh hasil batu curing sebesar 5\% dari total batu kapur yang dibakar per proses.

Selain defect berupa batu curing, juga ada defect berupa kosentrasi $\mathrm{CaO}$ yang dibawah standar, Insoluble Meter (IM) terlalu tinggi dan butiran.

Berdasarkan hasil sampling terhadap produk akhir selama periode Februari - April 2006, dari 5000 sampel ditemukan 557 cacat minor yaitu :

$\checkmark 254$ sampel mengandung cacat kosentrasi yang dibawah standar (45.6\%).

$\checkmark 145$ sampel terdapat cacat IM (28.4\%).

$\checkmark 158$ sampel mempunyai cacat butir (26\%).
Defect yang terjadi pada proses pembakaran batu kapur harus diminimalkan. Dalam penelitian ini akan difokuskan pada defect kadar $\mathrm{CaO}$ yang dapat terjadi pada semua type pembakaran yang dipergunakan, baik system burner dengan bahan bakar cair atau tradisional.

\section{Identifikasi Flow Proses}

Identifikasi flow proses merupakan salah satu alat Six Sigma yang paling esensial dalam mendokumentasikan proses. Secara keseluruhan flow proses pembuatan produk $\mathrm{CaO}$ dimulai dari proses pengambilan bahan baku pada tambang Batu Kapur sampai dengan pengantongan dan penyimpanan dapat dilihat dalam gambar 4 .

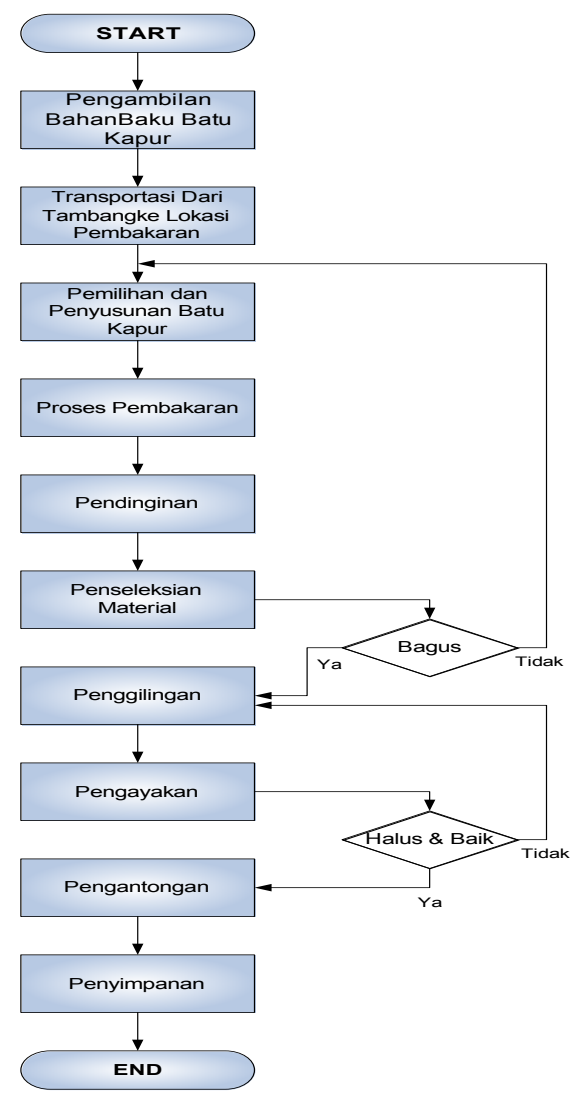

Gambar 3.Flow Proses Pembuatan $\mathrm{CaO}$

Penyusunan batu kapur di dalam tungku merupakan langkah penting untuk terlaksananya proses pembakaran yang efisien dan merata ke seluruh umpan batu kapur yang akan dibakar sehingga seluruhnya terkalsinasi menjadi $\mathrm{CaO}$.

Di bagian dasar disusun batu kapur berukuran besar $20-30 \mathrm{~cm} \times 30-40 \mathrm{~cm}$. Susunan ini berfungsi sebagai fondasi untuk menopang susunan batu kapur selanjutnya sampai ke bagian atas tungku agar pada saat pembakaran tidak longsor atau jatuh dikarenakan penataan tidak sempurna dan 
itu dibutuhkan tenaga ahli yang sudah terbiasa melakukan hal tersebut. Untuk penataan dalam kapasitas $25-30$ ton dibutuhkan waktu $1-2$ hari baru dilakukan persiapan untuk pembakaran.

Pembakaran dimulai dengan api kecil menggunakan kayu bakar untuk mengeringkan batu kapur. Api dapat dibesarkan setelah batu kapur hampir kering sehingga uap air tidak terlalu banyak. Banyaknya uap air akan mengganggu draft (tarikan) sehingga pembakaran kurang lancar, banyak menghasilkan jelaga yang mengganggu proses pembakaran selanjutnya.

Proses pembakaran membutuhkan minimal satu orang untuk menjaga agar proses tetap berlangsung sampai terjadinya pembakaran sempurna, untuk terjadinya pembakaran sempurna membutuhkan waktu $5-6$ hari. Setelah pembakaran selesai dibiarkan 1 hari untuk proses pendinginan setelah itu dilakukan pembongkaran dengan memilih batu kapur yang sudah terkalsinasi dengan batu kapur yang masih mentah / tidak bisa diproses (batu Curing). Setelah proses pembongkaran di lanjutkan proses penggilingan, sebelum penggilingan dilakukan pemecahan dari batu besar dipecah menjadi kecil-kecil sesuai yang dikehendaki untuk mempermudah proses penggilingan juga dilakukan set up mesin giling sesuai permintaan konsumen termasuk ukuran ayakan yang dikehendaki, apabila dalam proses terdapat butiran yang tidak sesuai dilakukan proses penggilingan ulang dan seterusnya.

Proses pengantongan dengan cara manual dengan menggunakan alat timbang yang kapasitasnya besar untuk satu kantong / bag kapur aktif beratnya 50 $\mathrm{kg}$ sedang kantong didalamnya diberi inert (plastik tipis) kedap udara agar konsentrasi kapur aktif tidak turun dikarenakan kelembaban udara. Setelah proses pengantongan produk dikirim ke gudang penyimpanan dan siap di kirim ke konsumen.

\section{Measure}

Measure adalah tahap kedua dalam siklus DMAIC.

\section{Identifikasi Karakteristik Kritis Terhadap Kualitas ( CTQ )}

Six Sigma yang difokuskan pada cacat dan variasi, dimulai dengan mengidentifikasi unsurunsur kritis terhadap kualitas (CTQ) dari produk $\mathrm{CaO}$ sebagai berikut :
1. Kandungan $\mathrm{CaO}$ aktif
$\min : 65 \%$
2. Insuluble Meter (IM)
$\max : 2 \%$

\section{Ukuran butiran (Size) $\quad \min : 90 \%$}

\section{Identifikasi Defect Minor Pada Hasil Proses Produksi}

Seperti yang telah dijelaskan pada sub bab pertama bahwa yang akan diperbaiki adalah kapur aktif yang memiliki jenis defect minor. Identifikasi defect minor tersebut dilakukan pada produk akhir. Dikarenakan perusahaan PT. Giri Mulya Jatim sudah tidak memiliki lagi laboratorium pengukuran maka hasil defect minor didasarkan pada report / informasi dari konsumen (PT. Petrokimia Gresik) sesuai dengan spesifikasi yang ditetapkan seperti kandungan $\mathrm{CaO}$ aktif, Insuluble Meter dan Ukuran butiran (size) selama bulan Februari - April 2006 yang telah teridentifikasi sebagai berikut:

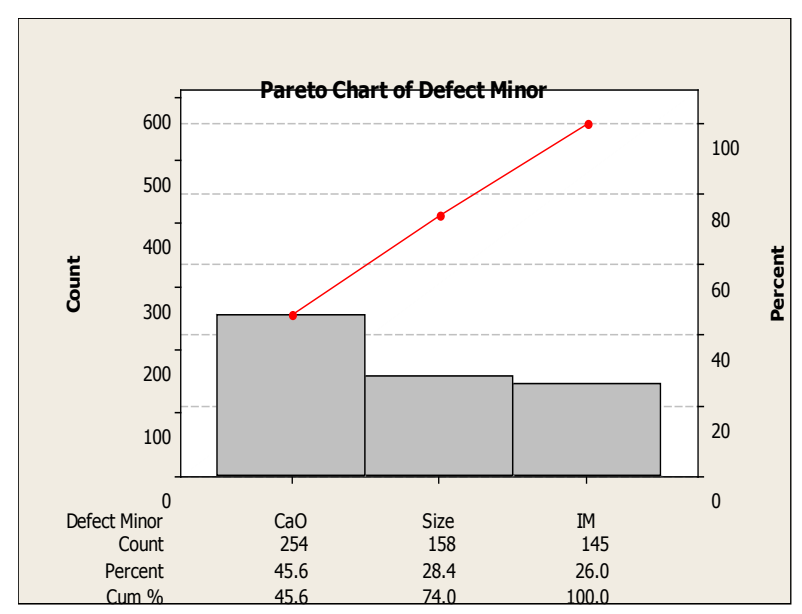

Gambar 4. Pareto Chart Defect Minor

\section{Mengukur Baseline Kinerja (Performance Baseline)}

Pengukuran baseline kinerja dilakukan untuk mengetahui tingkat kinerja selama 3 bulan, sehingga dapat ditetapkan target yang ingin dicapai berupa penurunan defect $\mathrm{CaO}$. Baseline kinerja dalam penelitian ini menggunakan satuan pengukuran DPMO (Defect Per Million Opportunities) sebesar 37133 dan kapabilitas Sigma 3,285.

\section{Cost of Poor Quality (COPQ)}

Penurunan kualitas produk $\mathrm{CaO}$ menimbulkan biaya-biaya. Biaya-biaya tersebut muncul karena kerugian atas biaya produksi yang telah dikeluarkan untuk unit-unit produk yang ditolak. Pada kasus produk $\mathrm{CaO}$ terdapat dua macam biaya yang harus ditanggung oleh PT Giri Mulya Jatim sebagai akibat adanya penurunan kualitas, yaitu :

1. Biaya sampling kualitas $\mathrm{CaO}$.

2. Biaya proses rework yang harus dikeluarkan. 
Berdasarkan rekapan 3 bulan terakhir maka dapat di jelaskan dibawah :

Tabel 1. Penghitungan Defect kedalam COPQ

\begin{tabular}{|c|c|c|c|c|c|c|c|}
\hline No & Defect & $\begin{array}{c}\text { Kuantitas } \\
\text { Inspeksi }\end{array}$ & $\begin{array}{c}\text { Kuantitas } \\
\text { Defect }\end{array}$ & DPMO & Sigma & COPQ & $\begin{array}{c}\text { Persentase } \\
(\%)\end{array}$ \\
\hline 1 & \multirow{4}{*}{$\begin{array}{l}\text { CaO Aktif } \\
\text { Ukuran butiran } \\
\text { (Size) } \\
\text { Insuluble Meter } \\
\text { (IM) } \\
\text { Proses }\end{array}$} & \multirow{4}{*}{5000} & 254 & 16933.3333 & 3.622 & 76200000 & 5.08 \\
\hline 2 & & & 158 & 10533.3333 & 3.807 & 47400000 & 3.16 \\
\hline 3 & & & 145 & 9666.66667 & 3.839 & 43500000 & 2.9 \\
\hline & & & 557 & 37133.3333 & 3.285 & 167100000 & 11.14 \\
\hline
\end{tabular}

Identifikasi Sumber-Sumber DanAkar Penyebab Masalah Defect Minor CaO

Untuk mengatasi cacat-cacat yang tergolong sebagai CTQ maka faktor-faktor penyebab munculnya cacat-cacat tersebut distrukturkan dalam bentuk fish bone diagram. Fish bone diagram dibentuk melalui pengamatan di lapangan dan diskusi di antara anggota tim six sigma. Berdasarkan hasil brainstorming tersebut maka didapatkan sumber dan akar penyebab dari masalah defect minor $\mathrm{CaO}$, serta mendapatkan solusi masalah yang efectif dan efisien. Jenis cacat yang akan dianalisa adalah cacat kadar $\mathrm{CaO}$, IM dan butir yang terjadi pada proses produksi.

\section{Cacat kadar $\mathrm{CaO}$}

Batu kapur dapat terjadi dengan beberapa cara, yaitu secara organik, secara mekanik, atau secara kimia. Sebagian besar batu kapur yang terdapat di alam terjadi secara organik, jenis ini berasal dari pengendapan cangkang/rumah kerang dan siput, foraminifera atau ganggang, atau berasal dari kerangka binatang koral/kerang. Batu kapur dapat berwarna putih susu, abu muda, abu tua, coklat bahkan hitam, tergantung keberadaan mineral pengotornya.

Cacat kadar $\mathrm{CaO}$ dapat dipengaruhi oleh pemilihan material awal batu kapur yang tidak diuji laboratorium terlebih dahulu walau rata-rata kandungan yang terdapat pada daerah penambangan sebesar $30-89 \%$ kalsium (Ca), akan tetapi belum tentu homogen. Komposisi kimia batu kapur sangat bervariasi pada tiap daerah dan cadangannya (P.S. Dwivedi, 2004). Material yang dipergunakan oleh perusahaan terdiri dari atas dua jenis batu kapur yang dilihat secara visual terdiri atas dua jenis yaitu : berwarna putih dan putih kekuningan. Disamping itu dapat terjadi pada proses pembakaran batu kapur yang tidak sempurna.

\section{Cacat IM}

Pengotoran yang terjadi pada $\mathrm{CaO}$ dapat berakibat pada meningkatnya IM karena $\mathrm{CaCO}_{3}$ yang ada dialam tidaklah murni. Selain dari pengotoran, dapat juga terjadi dalam proses itu sendiri yang berupa material yang tidak berubah menjadi $\mathrm{CaO}$, sehingga berpengaruh ketika digiling dan diayak, masih tetap ada. Berdasarkan hasil pengamatan dan wawancara dengan pihak yang terlibat, cacat IM juga disebabkan oleh faktor dari operator yang kurang hati-hati dalam melakukan proses sehingga tercampur dengan abu hasil pembakaran atau tanah.

\section{Cacat butir}

Ukuran butir yang diinginkan konsumen sebesar mesh 100 dan dari pengamatan pada periode Februari - April 2006 mempunyai cacat yang paling kecil dibandingkan jenis cacat yang lainnya. Type cacat butir ini disebabkan oleh pembakaran dan penggilingan pada proses produksi. Pada proses produksi terjadi secara microstruktur dari pembentukan $\mathrm{CaO}$ itu sendiri. Tegangan yang terjadi pada material yang terbakar memberi pengaruh perubahan struktur dari $\mathrm{CaCO}_{3}$ menjadi $\mathrm{CaO}$ dan $\mathrm{CO}_{2}$, perubahan ini tidaklah stabil karena $\mathrm{CaO}$ bersifat tidak stabil, dapat berubah menjadi stabil ketika tercampur dengan air dan menjadi kapur mati. Ketika perubahan material inilah, yang menentukan ukuran butir pada $\mathrm{CaO}$. Selain itu juga dapat terjadi pada proses penggilingan dan penggayakan yang disebabkan alat penggayakan yang tidak sesuai kebutuhan serta tercampur dengan ukuran lainnya.

\section{Improve}

\section{Menetapkan Variabel Respon}

Berdasarkan CTQ yang ada, maka dapat dirumuskan karakteristik kualitas yang digunakan. Karakteristik kualitas kadar $\mathrm{CaO}$ dan butir adalah Large The Better (LTB) sehingga semakin tinggi kadar dan kehalusan butiran semakin baik kualitasnya, sedangkan IM adalah Small The Better (STB), semakin kecil IM semakin bagus $\mathrm{CaO}$. Karakteristik kualitas yang dijadikan tujuan perbaikan dalam penelitian ini adalah kadar $\mathrm{CaO}$, 
berdasarkan diagram pareto, jenis cacat yang terbesar yaitu 45,6\%.

\section{Menetapkan Variabel Bebas}

Varibel-variabel yang terlibat dalam eksperimen ini, berdasarkan pengamatan dan wawancara, serta diagram sebab akibat yang terdiri dari faktor yang terkontrol (control factor) dan faktor yang tidak dapat dikontrol (noise faktor) serta levelnya. Pemilihan level pada masing-masing faktor terkendali dilakukan berdasarkan metode yang sekarang digunakan oleh para pengusaha batu kapur di Jatim.

\section{Control Faktor}

Variabel bebas atau faktor terkendali yang berpengaruh terhadap kualitas $\mathrm{CaO}$ adalah sebagai berikut :

a. Jenis batu kapur (Faktor A) yang dipergunakan yang terdiri dari dua jenis yaitu :

i. Batu kapur berwarna putih (Level 1)

ii. Batu kapur berwarna putih kekuningan (Level 2)

b. Ukuran batu kapur (Faktor B) yang akan dibakar yaitu :

i. $\quad 2-5 \mathrm{~cm}$ (kecil), (Level 1)

ii. $\quad 6-10 \mathrm{~cm}$ (sedang), (Level 2)

c. Jenis bahan bakar (Faktor C) yang dipergunakan dalam proses pembakaran

i. Kayu dan batok kelapa (Level 1)

ii. Kayu dan batubara (6000 kkal/kg), (Level 2)

\section{Noise Faktor}

Variabel yang tidak dapat dikendalikan yang berpengaruh kepada kualitas $\mathrm{CaO}$, adalah sebagai berikut :

a. Jenis pembakaran yang dilakukan (Faktor N1)

i. Dibawah susunan batu kapur (Level 1)

ii. Diatas susunan batu kapur (Level 2)

b. Temperatur udara lingkungan (Faktor N2)

i. Diatas $32^{\circ} \mathrm{C}$ (Level 1)

ii. Dibawah $32^{\circ} \mathrm{C}$ (Level 2)

c. Kelembaban (Faktor N3)

i. Diatas $56 \%$ (Level 1)

ii. Dibawah 56\% (Level 2)

\section{Pemilihan Inner dan Outer Array}

Dalam rancangan eksperimen dengan Taguchi, penanganan faktor noise dilakukan dengan memasukkan ke dalam percobaan serta menempatkannya pada outer array atau melakukan pengulangan percobaan (Ross, 1989). Demikian juga untuk faktor yang terkontrol ditempatkan pada inner array.

Tabel 2. Inner/Outer OA Parameter Design Eksperimen

\begin{tabular}{|c|c|c|c|c|c|c|c|c|c|}
\hline \multirow{4}{*}{ Trial no. } & \multicolumn{7}{|c|}{ Inner Array (Control Factor) } & & \\
\hline & A & B & $\mathrm{AxB}$ & $\mathrm{C}$ & $\mathrm{AxC}$ & $\mathrm{BxC}$ & Error & & \\
\hline & \multicolumn{7}{|c|}{ Colomn no. } & & \\
\hline & 1 & 2 & 3 & 4 & 5 & 6 & 7 & $\mathrm{Y} 1$ & $\mathrm{Y} 2$ \\
\hline 1 & 1 & 1 & 1 & 1 & 1 & 1 & 1 & R11 & $\mathrm{R} 12$ \\
\hline 2 & 1 & 1 & 1 & 2 & 2 & 2 & 2 & $\mathrm{R} 21$ & R22 \\
\hline 3 & 1 & 2 & 2 & 1 & 1 & 2 & 2 & R31 & $\mathrm{R} 32$ \\
\hline 4 & 1 & 2 & 2 & 2 & 2 & 1 & 1 & R41 & $\mathrm{R} 42$ \\
\hline 5 & 2 & 1 & 2 & 1 & 2 & 1 & 2 & R51 & R52 \\
\hline 6 & 2 & 1 & 2 & 2 & 1 & 2 & 1 & R61 & R62 \\
\hline 7 & 2 & 2 & 1 & 1 & 2 & 2 & 1 & R71 & R72 \\
\hline 8 & 2 & 2 & 1 & 2 & 1 & 1 & 2 & $\mathrm{R} 81$ & R82 \\
\hline
\end{tabular}

\section{Perhitungan S/N Ratio}

Untukmengidentifikasi pengaruh faktorterhadap variabilitas prosentase cacat maka terlebih dahulu data hasil eksperimen ditransformasikan kedalam bentuk S/N (signal to noise ratio).

Dalam penelitian ini, karakteristik kualitas yang dipakai adalah LTB (large the better), dimana tujuan perbaikan adalah memaksimumkan presentase kadar $\mathrm{CaO}$.

Tabel 3. : Hasil perhitungan $\mathrm{S} / \mathrm{N}$ pada setiap eksperimen

\begin{tabular}{|c|c|c|c|c|c|c|}
\hline \multirow{2}{*}{ Eksper. } & \multicolumn{4}{|c|}{ Hasil Eksperimen (\%) } & \multirow{2}{*}{$\begin{array}{l}\text { Rata-rata } \\
\text { Replikasi }\end{array}$} & \multirow{2}{*}{ S/N $(\mu)$} \\
\cline { 2 - 5 } & Repl.1 & Repl. 2 & Repl. 3 & Repl. 4 & Rep \\
\hline 1 & 75.28 & 64.99 & 71.85 & 79.86 & 73.00 & -37.30 \\
\hline 2 & 80.76 & 74.18 & 72.89 & 81.62 & 77.36 & -37.79 \\
\hline 3 & 62.65 & 75.08 & 72.59 & 79.34 & 72.42 & -37.24 \\
\hline 4 & 72.29 & 72.22 & 72.04 & 74.12 & 72.67 & -37.23 \\
\hline
\end{tabular}




\begin{tabular}{|l|l|l|l|l|l|l|}
\hline 5 & 69.86 & 69.10 & 65.43 & 79.23 & 70.91 & -37.04 \\
\hline 6 & 67.94 & 71.30 & 76.13 & 78.07 & 73.36 & -37.33 \\
\hline 7 & 69.55 & 71.09 & 75.02 & 73.66 & 72.33 & -37.19 \\
\hline 8 & 71.65 & 68.34 & 73.32 & 82.07 & 73.85 & -37.39 \\
\hline
\end{tabular}

\section{Perhitungan Anova}

Hasil perhitungan ANOVA untuk karakterisitik prosentase cacat pada pembakaran batu kapur

dengan menggunakan bantuan software MINITAB dapat ditampilkan pada tabel berikut :

Tabel 4. : ANOVA Rasio S/N Presentase Kadar CaO

\begin{tabular}{|l|c|r|r|r|r|r|}
\hline Source & DF & \multicolumn{1}{c|}{ Seq SS } & \multicolumn{1}{c|}{ Adj SS } & Adj MS & \multicolumn{1}{c|}{ F } & F tabel \\
\hline $\mathrm{A}$ & 1 & 1.4112 & 1.4112 & 1.4112 & 27.56 & 39.86 \\
\hline $\mathrm{B}$ & 1 & 6.444 & 6.444 & 6.444 & 125.86 & 39.86 \\
\hline $\mathrm{C}$ & 1 & 9.202 & 9.202 & 9.202 & 179.73 & 39.86 \\
\hline $\mathrm{A} * \mathrm{~B}$ & 1 & 3.125 & 3.125 & 3.125 & 61.04 & 39.86 \\
\hline $\mathrm{A}{ }^{*} \mathrm{C}$ & 1 & 3.1752 & 3.1752 & 3.1752 & 62.02 & 39.86 \\
\hline $\mathrm{B}$ C & 1 & 1.264 & 1.264 & 1.264 & 24.69 & 39.86 \\
\hline Error & 1 & 0.0512 & 0.0512 & 0.0512 & & \\
\hline Total & 7 & 24.6727 & & & & \\
\hline
\end{tabular}

\section{Persen Kontribusi}

Persen kontribusi digunakan untuk mengetahui sumbangan dari faktor utama dan interaksi yang signifikan. Berdasarkan tabel 4.5, faktor yang signifikan adalah ukuran batu kapur (B), jenis bahan bakar (C), interaksi jenis batu kapur dan ukuran batu kapur (AxB), dan jenis batu kapur dan jenis bahan bakar $(\mathrm{AxC})$.

Persen kontribusi faktor utama dan faktor interaksi untuk variabel respon kadar $\mathrm{CaO}$ adalah seperti pada tabel 5.9 berikut ini :

Tabel 5. Persentase Kontribusi Faktor Presentase Kadar $\mathrm{CaO}$

\begin{tabular}{|l|c|r|r|r|r|r|}
\hline Source & DF & \multicolumn{1}{|c|}{ Seq SS } & Adj SS & Adj MS & \multicolumn{1}{c|}{ SS' } & $\begin{array}{c}\text { Percent } \\
\text { kontribusi }\end{array}$ \\
\hline B & 1 & 6.444 & 6.444 & 6.444 & 6.5352 & $26.49 \%$ \\
\hline C & 1 & 9.202 & 9.202 & 9.202 & 9.2932 & $37.67 \%$ \\
\hline A*B & 1 & 3.125 & 3.125 & 3.125 & 3.2162 & $13.04 \%$ \\
\hline A*C & 1 & 3.1752 & 3.1752 & 3.1752 & 3.2664 & $13.24 \%$ \\
\hline Error & 3 & 2.7264 & 2.7264 & 0.9088 & & \\
\hline Total & 7 & 24.6727 & & & & \\
\hline
\end{tabular}

\section{Kombinasi Level Optimum dan Prediksi S/N}

\section{Ratio}

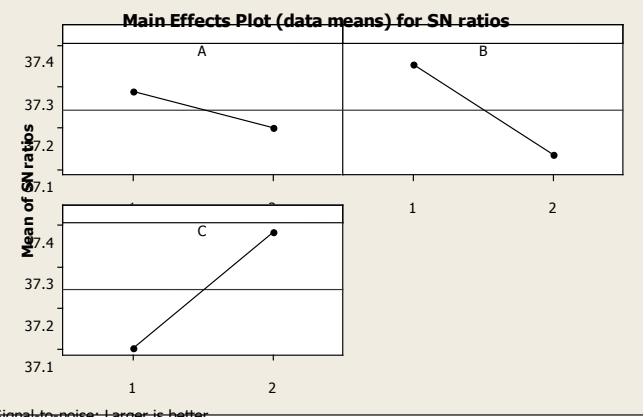

Gambar 5. Plot Pengaruh Faktor Utama Respon $\mathrm{CaO}$

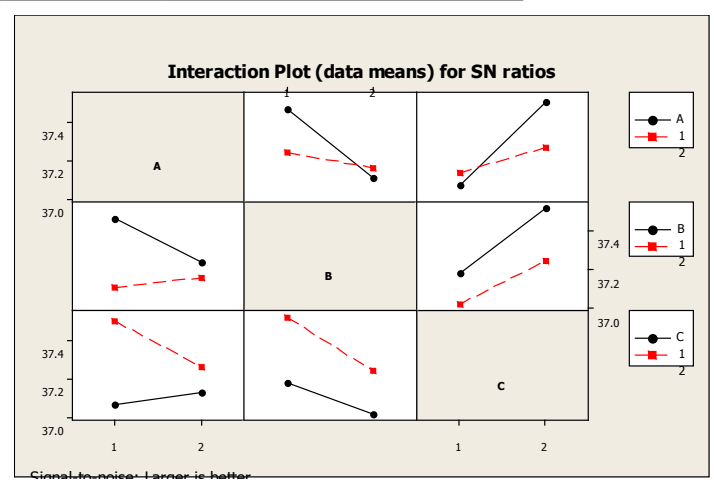

Gambar 6. Plot Pengaruh Interaksi antar Faktor Utama pada $\mathrm{CaO}$

Faktor-faktor yang signifikan yaitu ukuran batu kapur $\left(\mathrm{B}_{2}\right)$, jenis bahan bakar $\left(\mathrm{C}_{2}\right)$, interaksi jenis batu kapur dan ukuran batu kapur (AxB), dan jenis 
batu kapur dan jenis bahan bakar (AxC) sehingga untuk respon kadar $\mathrm{CaO}$, taksiran kondisi optimum dapat dimodelkan sebagai berikut :

$$
\begin{aligned}
& \mathrm{S} / \mathrm{N}_{\text {optimum }}= \\
& \bar{y}+\left(\overline{B_{1}}-\bar{y}\right)+\left(\overline{A_{2} B_{1}}-\bar{y}\right)+\left(\overline{C_{2}}-\bar{y}\right)+\left(\overline{A_{2} C_{2}}-\bar{y}\right) \\
& \mathrm{S} / \mathrm{N}_{\text {optimum }}=-37,28
\end{aligned}
$$

\section{Interval Kepercayaan}

Interval kepercayaan untuk taksiran kondisi optimum pada tingkat kepercayaan $90 \%$ adalah

$$
\text { CI } \quad=-37,28 \pm \sqrt{F_{\mathrm{a}, 1,3} \times\left(\frac{\mathbb{M}_{e}}{2 / 1+V_{B}+V_{C}+V_{A x B}+V_{A x C}}\right)}
$$

$$
\mathrm{CI}=-37,28 \pm 0,887
$$

Hasil perhitungan kondisi optimum jika dikonversikan ke dalam nilai MSD, maka :

$$
\mathrm{S} / \mathrm{N}=-10 \log \mathrm{MSD}
$$

$$
\begin{array}{ll}
\mathrm{MSD} & =10^{(-\mathrm{S} N \mathrm{~N}) / 10} \\
& =0,000187 \\
\text { jadi } & \\
\mathrm{y}_{\text {taksiran }} & =\sqrt{\mathrm{MSD}} \\
& =0,013677
\end{array}
$$

Dengan demikian dari hasil penelitian diperoleh $\mathrm{S} / \mathrm{N}$ optimum untuk respon kadar $\mathrm{CaO}$ sebesar 37,28 . Dengan selang kepercayaan $90 \%$ diperoleh batas interval kepercayaan antara $-38,167<\mathrm{S} /$ $\mathrm{N}_{\text {optimum }}<-36,393$.

\section{Eksperimen Konfirmasi}

Percobaan konfirmasi bertujuan untuk membuktikan apakah faktor atau level optimum yang diperoleh dari percobaan utama dapat mengoptimalkan respon kadar $\mathrm{CaO}$. Pada percobaan konfirmasi untuk respon respon kadar $\mathrm{CaO}$ dilakukan 4 kali pengulangan dengan 2 kali pengujian. Hasil percobaan konfirmasi ditabelkan sebagai berikut :

Tabel 6. Percobaan Konfirmasi.

\begin{tabular}{|c|c|c|c|c|}
\hline Respon & $\begin{array}{c}\text { Kondisi Optimal Awal } \\
A_{1} B_{1} C_{2}\end{array}$ & CI Konfirmasi & $\begin{array}{c}\text { Kondisi Optimal } \\
\text { Percobaan } A_{1} B_{1} C_{2}\end{array}$ & Peningkatan \\
\hline $\begin{array}{c}\text { Persentase } \\
\text { kadar } \\
\text { CaO }\end{array}$ & $\begin{array}{c}\text { S/N opt. }=-37,28 \\
\text { MSD }=0,000187\end{array}$ & $-37,28 \pm 0,887$ & $\begin{array}{c}\text { S/N opt. }=-37,57 \\
\text { MSD }=0.067523\end{array}$ & 0,29 \\
\hline
\end{tabular}

Dari tabel 5.13 di atas terlihat kondisi optimum percobaan menghasilkan peningkatan nilai $\mathrm{S} / \mathrm{N}$ terhadap respon kadar $\mathrm{CaO}$ dibandingkan dengan kondisi optimum perusahaan (awal).

Karena hasil dari percobaan konfirmasi untuk respon kadar $\mathrm{CaO}$ terletak pada selang kepercayaan di atas, dapat disimpulkan bahwa faktor dan level yang dihasilkan pada percobaan utama telah sesuai dengan apa yang diharapkan.

\section{Tahap Control}

Control adalah tahap kelima dalam siklus DMAIC. Tahap ini berfokus untuk menyusun dan mengimplementasikan sebuah mekanisme kontrol untuk menghindari munculnya cacat yang dikategorikan sebagai Crititical To Quality agar tidak muncul kembali.

\section{Mekanisme kontrol}

Untuk menghindari munculnya cacat perlu dilakukan pengontrolan terhadap kualitas $\mathrm{CaO}$. Pada saat ini perusahaan belum menerapkan quality kontrol pada proses pembakaran batu kapur disebabkan oleh minimnya SDM oleh karena itu untuk implementasi kontrol dalam bentuk ceksheet tidak dapat diterapkan.

Perhitungan Kapasitas Proses

42
Kapasitas produksi berdasarkan percobaan yang dilakukan dari $250 \mathrm{gr}$ batu kapur menghasilkan 84 gr batu curing dan 92.96 gr CaO. Besarnya defek mayor dalam percobaan ini adalah 33,6\% dan hal ini disebabkan kurang standarnya tungku yang dipergunakan. Berdasarkan pengamatan dan wawancara dengan pihak perusahaan, bahwa kapasitas produksi untuk 100 ton batu kapur, menghasilkan 56 ton $\mathrm{CaO}$.

\section{Perhitungan Level Sigma}

Implementasi perbaikan untuk meningkatkan kualitas $\mathrm{CaO}$ harus dievaluasi untuk mengetahui perubahan nilai DPMO, dan level sigma. Dari hasil uji konfirmasi produksi $\mathrm{CaO}$ dengan 8 replikasi.

Terjadi perubahan nilai DPMO dan level sigma antara kondisi sebelum penelitian dan sesudah tahap improve. DPMO naik dari 37.133 menjadi 41.667. Sedangkan level sigma turun dari 3,3 menjadi 3,2. Hal ini disebabkan belum dilakukanya improve ke dalam perusahaan dan sedikitnya jumlah unit yang diinspeksi.

\section{Quality Loss Function}

Karakteristik kualitas untuk percentase kadar $\mathrm{CaO}$ adalah lebih besar lebih baik (LTB), maka bentuk loss function yang akan dipakai adalah 
sebagai berikut :

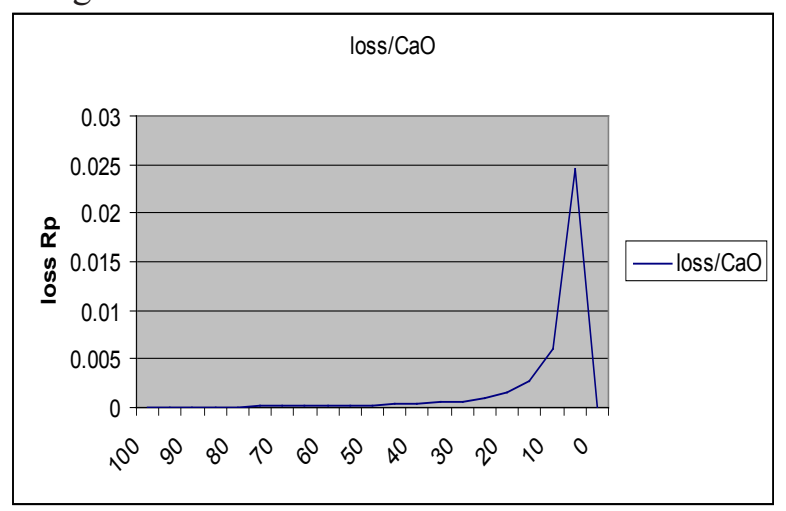

\section{Cleaner Production}

Upaya pencegahan pencemaran secara sistematis dapat dilaksanakan melalui pelaksanaan program cleaner production. Untuk proses cleaner production mencakup upaya konservasi bahan baku dan energi, menghindari pemakaian bahan mengandung B3 (bahan berbahaya dan beracun), mengurangi jumlah dan toksisitas semua limbah dan emisi yang dikeluarkan pada proses.

Pada penelitian ini, hanya difokuskan pada energi yang terbuang pada tungku pembakaran dan dampak proses pembakaran batu kapur terhadap lingkungan berupa tumbuhan jagung.

\section{Energi}

Proses pembakaran batu kapur merupakan industri padat energi karena $45 \%-60 \%$ biaya produksinya merupakan biaya energi. Efisiensi yang dihasilkan dalam proses pembakaran tidak $100 \%$, dikurangi rugi-rugi. Salah satu rugirugi yang terjadi adalah panas yang terbuang keluar dari sistem pembakaran secara konduksi yang disebabkan adanya perbedaan suhu dalam pembakaran dengan udara lingkungan dan panas yang keluar pada cerobong secara langsung.

Energi panas yang hilang dalam proses pembakaran batu kapur secara konduksi tidak mudah untuk dimanfaatkan karena energi panas tersebut tidak terkonsentrasi dan tersebar dalam area yang besar, meskipun jumlahnya besar.

Perhitungan konduksi yang terjadi pada proses batu kapur sebagai berikut :

$$
Q=2 \mathrm{p} k \frac{T_{1}-T_{2}}{\mathrm{~h}\left(r_{1} / r_{2}\right)}
$$

Dimana :

Q : Heat flow bentuk silinder (watt)

$\mathrm{K}$ : Thermal conductivity $\left(\mathrm{W} / \mathrm{m} \mathrm{C}^{0}\right)$

$\mathrm{T}_{1} \quad$ : Insert Temperature $\left(\mathrm{C}^{0}\right)$

$\mathrm{T}_{2} \quad$ : Outside Temperature $\left(\mathrm{C}^{0}\right)$

$\mathrm{r}_{1} \quad:$ Radius insert (m)

$r_{2} \quad$ : Radius outside (m)

Dinding yang dipergunakan untuk pembuatan tungku terdiri dari bata dan campuran semen dengan nilai konduktivitasnnya adalah $1.04 \mathrm{~W} / \mathrm{m}$ $\mathrm{C}^{0}$, radius luarnya adalah 5 meter dan radius dalam 3.7 meter, sedangkan temperature udara lingkungan adalah $32 \mathrm{C}^{0}$.

Tabel 7. Heat Loss pada proses batu kapur berdasarkan tingginya

\begin{tabular}{|c|c|c|c|c|}
\hline \multirow[b]{2}{*}{ No } & \multirow{2}{*}{$\begin{array}{l}\text { Ketinggian } \\
\text { (m) }\end{array}$} & \multicolumn{2}{|c|}{ Suhu $\left(C^{0}\right)$} & \multirow{2}{*}{$\begin{array}{c}\mathrm{Q} \\
\text { (Watt) }\end{array}$} \\
\hline & & $\begin{array}{c}\text { Dinding } \\
\text { luar }\end{array}$ & $\begin{array}{c}\text { Dinding } \\
\text { dalam }\end{array}$ & \\
\hline 1 & 0.5 & 130 & 228 & -2125.7 \\
\hline 2 & 1 & 124 & 216 & -1995.6 \\
\hline 3 & 2 & 108 & 184 & -1648.5 \\
\hline 4 & 3 & 87 & 142 & -1192.9 \\
\hline 5 & 4 & 73 & 114 & -889.3 \\
\hline 6 & 5 & 60 & 88 & -607.3 \\
\hline
\end{tabular}

Dari tabel diatas, tanda min pada heat flow (Q), menandakan bahwa panas mengalir keluar sistem pembakaran batu kapur dan dapat diambil kesimpulan bahwa, energi panas yang terbuang berbanding lurus dengan kenaikan suhu. Jika terjadi selama 1 jam dapat dikonversi ke watt hour (WH). Harga listrik $1 \mathrm{kWh}$ adalah Rp. 68 untuk golongan I-1(berdasarkan surat menteri pertambangan dan energi, tanggal 25 maret 1989).

Energi panas yang terbuang dapat dikonversikan ke biaya sebagai berikut :

Tabel 8. Biaya Heat Loss pada proses batu kapur berdasarkan tingginya

\begin{tabular}{|c|r|r|r|}
\hline No & Q (watt) & \multicolumn{1}{c|}{ kWh } & \multicolumn{1}{c|}{ Loss(Rp) } \\
\hline 1 & 2125.70 & 2.126 & 144.55 \\
\hline 2 & 1995.55 & 1.996 & 135.70 \\
\hline 3 & 1648.50 & 1.648 & 112.10 \\
\hline 4 & 1192.99 & 1.193 & 81.12 \\
\hline 5 & 889.32 & 0.889 & 60.47 \\
\hline 6 & 607.34 & 0.607 & 41.30 \\
\hline
\end{tabular}

\section{Dampak Polusi}

Udara merupakan salah satu komponen lingkungan yang sangat penting peranannya dalam kehidupan dan dalam kehidupan normal, udara mempunyai komposisi nitrogen $(78,08 \%)$, oksigen $(0,95 \%)$, karbondioksida $(0,0314 \%)$, dan sisanya 
merupakan gas-gas lain. Masuknya berbagai bahan pencemarke udara, akan merubah komposisi normal dan kualitas udara akan mengalami perubahan.

Proses pembakaran batu kapur dapat berdampak pada makhluk hidup, termasuk tumbuh-tumbuhan, misalkan tumbuhan jagung yang merupakan tumbuhan semusim yang sensitif terhadap polusi udara. Dari hasil penelitian ini, pengaruh pajanan emisi gas buang dalam proses pembakaran batu kapur pada tumbuhan jagung ditunjukan dengan adanya gejala kerusakan pada daunnya. Secara morfologi gejala kerusakan ini berupa spot bewarna putih kekuningan, akibat daun mengalami chlorosis dan diduga berasal dari pengaruh gas $\mathrm{NO}_{x}$ atau $\mathrm{SO}_{x}$ yang berasal dari hasil pembakaran kayu dan batubara. Secara anatomis, kerusakan dapat berdampak pada stomata daun karena stomata merupakan tempat terjadinya pertukaran gas dengan udara luar. Kerusakan pada stomata yang diakibatkan oleh pajanan emisi pada proses pembakaran batu kapur, tampak dengan adanya perubahan bentuk dari stomata seperti gambar dibawah ini :

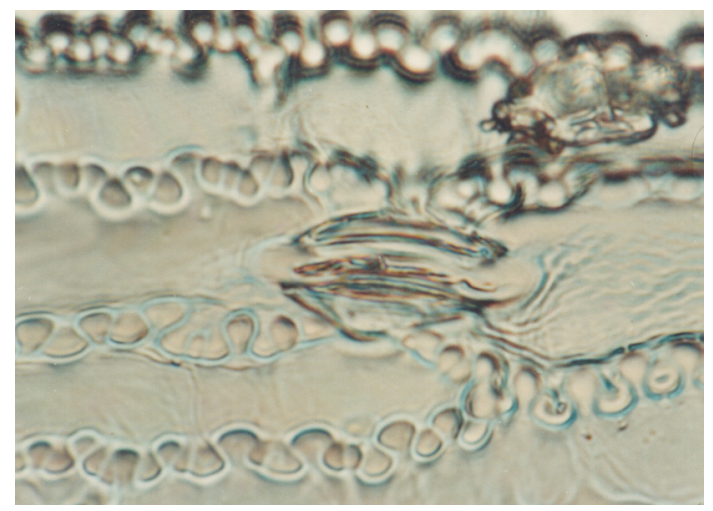

Gambar 8. Kerusakan bentuk stomata daun jagung pada pajanan emisi gas buang proses pembakaran batu kapur selama 7 jam dengan bahan bakar kayu dan batubara

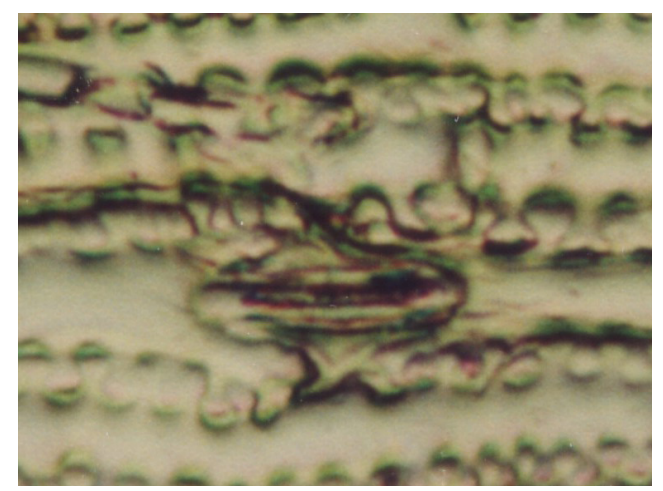

Gambar 9. Kerusakan bentuk stomata daun jagung pada pajanan emisi gas buang proses pembakaran batu kapur selama 7 jam dengan bahan bakar kayu dan batok kelapa

\section{KESIMPULAN}

Kesimpulan yang dapat ditarik dari penelitian ini ialah :

1. Terdapat dua jenis cacat yang diidentifikasi pada produk $\mathrm{CaO}$ yang dihasilkan oleh PT. Giri Mulya Jatim pada proses pembakaran $\mathrm{CaCO}_{3}$ berupa defect mayor yang berupa batu curing sebesar 5\% dari batu kapur yang dibakar dan defect minor yang terdiri dari 5000 sampel ditemukan :

a. Kadar persentase $\mathrm{CaO}$ yang dibawah standar sebesar $45.6 \%$ dari 254 sampling.

b. Insoluble Meter (IM) sebesar $28.4 \%$ dari 158 sampling.

c. Ukuran butir (Size) sebesar $26 \%$ dari 145 sampling.

2. Faktor dominan yang teridentifikasi sebagai penyebab ketidaksesuaian kandungan $\mathrm{CaO}$ berupa jenis batu kapur, ukuran batu kapur dan jenis bahan bakar yang dipergunakan. Faktor yang berpengaruh secara signifikan terhadap respon persentase kadar $\mathrm{CaO}$ pada percobaan utama adalah jenis bahan bakar berupa campuran kayu dan batubara $\left(\mathrm{C}_{2}\right)$, ukuran batu kapur yang dibakar dengan ukuran kecil $\left(\mathrm{B}_{1}\right)$, interaksi antara jenis batu kapur putih dan ukuran batu kapur $\left(\mathrm{A}_{2} \mathrm{~B}_{1}\right)$, interaksi antara jenis batu kapur putih dan jenis bahan bakar $\left(\mathrm{A}_{2} \mathrm{C}_{2}\right)$.

3. Kondisi optimum untuk respon persentase kadar $\mathrm{CaO}$ dicapai pada kombinasi level $\mathrm{A}_{1} \mathrm{~B}_{1} \mathrm{C}_{2}$ yaitu

a. Jenis batu kapur (A)

b. Ukuran batu kapur (B)

c. Jenis bahan bakar (C) : bewarna putih batubara $(6000 \mathrm{kkal} / \mathrm{kg})$

4. Nilai rasio $\mathrm{S} / \mathrm{N}$ optimum persentase kadar $\mathrm{CaO}$ adalah sebesar -37,28 dengan interval -38.167< $\mathrm{S} / \mathrm{N}_{\text {optimal }}<-36.393$ untuk tingkat kepercayaan $90 \%$.

5. Kontribusi faktor-faktor yang signifikan terhadap rata-rata rasio $\mathrm{S} / \mathrm{N}$ tingkat persentase kadar $\mathrm{CaO}$ adalah ukuran batu kapur (26.49\%), jenis bahan bakar(37.67\%), interaksi antara jenis batu kapur dan ukuran batu kapur (13.04\%), interaksi antara jenis batu kapur dan jenis bahan bakar (13.24\%).

6. Besarnya $\mathrm{S} / \mathrm{N}$ optimum pada percobaan 
konfirmasi untuk respon persentase kadar $\mathrm{CaO}$ adalah $-37,28 \pm 0.887$ dengan batas interval kepercayaan pada tingkat kepercayaan 90\%.

7. Kapasitas produksi berdasarkan percobaan yang dilakukan dari $250 \mathrm{gr}$ batu kapur menghasilkan 84 gr batu curing dan 92.96 gr CaO. Besarnya defek mayor dalam percobaan ini adalah 33,6\% dan hal ini disebabkan kurang standarnya tungku yang dipergunakan. Berdasarkan pengamatan dan wawancara dengan pihak perusahaan, bahwa kapasitas produksi untuk 100 ton batu kapur, menghasilkan 56 ton $\mathrm{CaO}$.

8. Terjadi perubahan nilai DPMO dan level sigma antara kondisi sebelum penelitian dan sesudah tahap improve. DPMO naik dari 37.133 menjadi 41.667. Sedangkan level sigma turun dari 3,3 menjadi 3,2. Hal ini disebabkan belum dilakukanya improve ke dalam perusahaan dan sedikitnya jumlah unit yang diinspeksi.

9. Koefisien fungsi kerugian pada perusahaan $0.6122 / \mathrm{kg}$ percentase kadar $\mathrm{CaO}$.

10.Proses pembakaran batu kapur tidak dapat menghasilkan efisiensi yang tinggi karena banyaknya rugi-rugi berupa aliran panas sebesar 2125,7 watt pada suhu $228 \mathrm{C}^{0}$ (dinding dalam tungku ) dengan biaya sebesar Rp 144.55 per jam.

11. Dampak pembakaran proses batu kapur pada tumbuhan jagung secara morfologis berupa spot bewarna putih kekuningan, akibat daun mengalami chlorosis dan diduga berasal dari pengaruh gas $\mathrm{NO}_{x}$ atau $\mathrm{SO}_{x}$ yang berasal dari hasil pembakaran kayu dan batubara. Secara anatomis kerusakan terlihat pada stomatanya.

\section{DAFTAR PUSTAKA}

Allen, D. T., and R. S. Butner, (Nov. 2002), "Industrial Ecology: A Chemical Engineering Challenge," Chem. Eng. Prog., 98(11).

Bar, Neil., et all, (2004), "Sustainability Module 8.5", Presentation for: ESD.60 - Lean/Six Sigma Systems MIT Leaders for Manufacturing Program (LFM).

Belavendram,N., (1991), Quality by Desaign : Taguchi Techniques for Industrial Exsperimentation, Prentice Hall, New York.

Benyus, J., (1997), "Biomimicry", William and Morrow, New York.

Bhavik R. Bakshi and Joseph Fiksel, (2003), "The Quest for Sustainability: Challenges for Process Systems Engineering", halaman 1350 June 2003
Vol. 49, No. 6 AIChE Journal

Bijl, M. et all, (Nov 2004), EU Market Survey 2004 Timber and Timber Products Compiled for CBI by: ProFound.

Carnegie, Kashonia L., Howard Nielsen, Colin Glover, (2000), Stepping upstream 'naturally' for cleaner production through community environmental learning, Journal of Cleaner Production 8.

Conner, Gary L., (Dec 2003), Moisture Susceptibility of Bottom Ash Asphalt Mixes, Thesis, University of Wyoming.

Fiksel, J., (Fall 2000), "Measuring Sustainability in Eco-Design," Sustainable Solutions: Developing Products and Services for the Future, M. Charter and U. Tischner, eds., Greenleaf Publishing, Sheffield, U.K.

Fiksel, J., (2003), "Revealing the Value of Sustainable Development," Corporate Strategy Today, VII/VIII.

Fiksel, J., (2002), "Sustainable Development through Industrial Ecology," Advancing Sustainability through Green Chemistry and Engineering, R. L. Lankey and P. T. Anastas, eds., American Chemical Society, Washington, DC.

Gale, Robert, (2005), Environmental management accounting as a reflexive modernization strategy in cleaner production, Journal of Cleaner Production xx.

Gaspersz, Prof. Dr. Vincent, D.Sc., CFPIM, CIQA (2002). Pedoman Implementasi Program Six Sigma Terintegrasi dengan ISO 9001:2000, MBNQA, Dan HACCP. Edisi pertama. Penerbit PT Gramedia Pustaka Utama, Jakarta.

Giadina, (2006), " Lean Six Sigma and Sustainability“, http://proceedings.ndia.org / JSEM2006/ Wednesday/ Giardina.pdf.

Gitlow, H.S. and S.J. Gitlow., (1987), The Deming guide to quality and competitive position, Prentice-Hall, Inc. Newark, NJ.

G. Howard, A. Oppenheim, R. oppenheim (1995). Quality Management Tools and Methods for Improvement. $2^{\text {nd }}$ Edition. Irwin Inc, Chicago.

Gumus, Bulent., (Dec 2005), Requirements Traceability (RT) Throughout the System Using Axiomatic Product Development Lifecycle, Dissertation, Texas Tech University.

Hayes, B. J., (2003), Improving offshore outsourcing efficiency with DFSS. Accessed at: http://software.isixsigma.com/library/content/ 
c031112a.asp.

Kjaerheim, Gudolf., (2005), Cleaner production and sustainability Journal of Cleaner Production 13.

Krumnacher, Paul J.,(2001), Lime and Cement Technology: Transition from Traditional to Standardized Treatment Methods, Thesis, Faculty of the Virginia Polytechnic Institute and State University.

Mader, D. M. (2002), Design for Six Sigma. Quality Progress, July, 82-86.

Mullins, G.L.,(2005), Sources of Lime for Acid Soils in Virginia, Produced by Agriculture and Extension Communications, Virginia Tech.

Black, Peter E., (2005), Ecological Sustainability: A New Look at an Old Paradigm Journal of Ecological Anthropology halaman 76 Vol. 9.

Pyzdek, Thomas (2002). The Six Sigma Handbook Panduan Lengkap untuk Greenbelts, Blackbelts, dan Manajer pada Semua Tingkat. Edisi Pertama. Penerbit Salemba Empat, Jakarta.

Richard G. Little, (2004), Tending the Infrastructure Commons:Ensuring the Sustainability of Our Vital Public Systems International Workshop on Integrated Life-Cycle Management of Infrastructures December 9-11, 2004 The Hong Kong University of Science and Technology Hong Kong SAR, PRC

Rittenhouse, D., (March 2003), "Piecing Together a Sustainable Development Strategy," Chem. Eng. Prog., 99(3), 32.

Roberts, F., P. Kandhal, E. Brown, D. Lee, and T. Kennedy (1996). Hot Mix Asphalt Materials, Mixture Design, and Construction. 2nd edition. Lanham, Maryland: NAPA Education Foundation.

Robèrt, K. H., (1997), The Natural Step: A Framework for Achieving Sustainability in Our Organizations, Pegasus, Cambridge, MA .

Ross,Philip J., (1996), Taguchi Techniques for Quality Engineering, McGraw-Hill.2 ${ }^{\text {nd }}$ ed., New York.

Saling, P., et al., (2002), "Eco-Efficiency Analysis by BASF: The Method," Int. J. of Life Cycle Assessment.

Smith, Purpose of Stabilization Typical Stabilizers Soil Stabilization, Modification http:// ceprofs.tamu.edu/smith/SmithSpring418-04/ CVEN418Lect24-0402.pdf

UNEP. (1993), Cleaner Production Worldwide. UNEP report, United Nations Environment
Programme.

Verfaillie, H.A., and R. Bidwell, (2000), "Measuring Eco-Efficiency: A Guide to Reporting Company Performance," WBCSD, Geneva.

Wang Hongtao, (2001), "Introduction of the course", Industrial Ecology HongtaoCollege of Material Science and Engineering, Sichuan University, Chengdu, China.

WBCSD, (2002), Toward a Sustainable Cement Industry, Battelle Memorial Institute.

WCED, (1987), World Commission on Environment and Development. Our Common Future, Oxford University Press, New York.

Wolf, J. Drivers for international integrated environmental management. In Ruth Hillary (ed.) ,(1997), Environmental management systems and cleaner production, Hoboken, NJ: John Wiley \& Sons.

Wurts, W. A. and R. M. Durborow., (1992), Interactions of $\mathrm{pH}$, carbon dioxide, alkalinity and hardness in fish ponds. 